\title{
The Influence of the Nature of Different Sands on the Rheological and Mechanical Behavior of Self-compacting Concretes
}

\author{
Baali Laid", Larbi Belagraa1, Zeghichi Leila1, and Benhamouda Abdelhakim² \\ ${ }^{1}$ University Mohamed Boudiaf - M'sila, Algeria \\ ${ }^{2}$ CMADE-Laboratory, Faculty of Engineering, University of Beira Interior, Portugal
}

\section{Abstract}

Self-compacting concretes represent a new advance for concrete construction because they offer many advantages from the economic, technical and social point of view. They are very fluid concretes, which are put in place without vibration. When pouring into a formwork, tightening a BAP is ensured by the simple effect of gravity. Thanks to their formulation, they offer exceptional flow characteristics and filling formwork while resisting perfectly segregation. Homogeneous and stable, they have resistances and durability similar to those of traditional concretes of which they are differentiated by

Corresponding Author:

Baali Laid

baali_laid@yahoo.fr

Received: 26 November 2019

Accepted: 13 May 2020

Published: 2 June 2020

Publishing services provided by Knowledge E

(c) Baali Laid et al. This article is distributed under the terms of the Creative Commons

Attribution License, which permits unrestricted use and redistribution provided that the original author and source are credited.

Selection and Peer-review under the responsibility of the ICEUBI2019 Conference Committee. their properties in the fresh state. The use of self-compacting concrete reduces the noise nuisance, as well as the hardness of the work. This research work is part of a policy of contributing to the improvement of the properties of self-compacting concretes prepared from local materials in the M'sila region. In this study, we are interested in obtaining the most suitable concrete formulation for the different local materials of the M'sila region. Our study is directed towards the effect of the following parameters on the physico-mechanical properties of the composite such as: dynamic segregation, spreading diameter as well as mechanical strengths (compression, traction). It is therefore a question of determining the criteria to be imposed on these parameters, in order to lead to the construction of a self-compacting concrete characterized by an acceptable resistance. The experimental results of compressive strengths show significant behaviors between BAP and BV. They allowed to distinguish a resistance gain between 15.11 and 49.28 , this gain is explained by a rehydration of the cement matrix due to the migration of the water through the pores for the BAP, but also to better binding properties of the hydrates forms.

Keywords: SCC, Rheological behavior, Mechanical resistance, Binder

\section{Introduction}

Self-compacting concretes (SCC) are very fluid concretes, whose specification is to be put in place under the effect of their own weight without adding vibration. The idea of these concretes was launched in the mid-1980s by researchers at the University of Tokyo and was quickly taken up by major Japanese industrial groups for major projects 
The essential asset of the SCCs, the vibration-free implementation generates a whole chain of advantages: reduction of the deadlines, improvement of the productivity, reduction of the equipment of lifting, quality of the facings increased, concreting easy of very high parts or very armed, considerable reduction of the toil for the workmen and gain of security.

This setting up under the sole effect of the gravity, need a very high fluidity of the materials but it is also essential that the concrete maintains a satisfactory stability and a perfect homogeneity. These two properties are obtained by:

- A high quantity of fine particles and a limited content of aggregates (coarse aggregates should be $50 \%$ of dry compacted bulk volume of coarse aggregate excluding air content;

- A low water / powder ratio, a high dosage of superplasticizer and viscosity stabilizer. [3-5].

SCCs are formulated to achieve the optimal compromise between fluidity and resistance to segregation and bleeding. They offer a higher aesthetic quality of the siding.

SCCs are used as well cast in place on site, delivered from concrete plants ready for use and generally implemented by pumping, then in prefabrication plant of concrete elements. They have in the cured state performance and durability similar to traditional concretes implemented by vibration.

The requirements and rules for the design and dimensioning of concrete structures are applicable to the SCCs, which makes it possible to use them in place of concretes with the same mechanical characteristics [6].

\section{Objectives}

The different properties of self-compacting concretes (viscosity, fluidity, segregation,...) make their composition relatively complicated.

It is in this context that the study conducted in this work is located. Attempts have been made to establish a composition of SCCs based on local material; evaluating the influence of the nature of the sand on the Physico-mechanical properties.

This study has three main parts:

- A Physico-chemical study of aggregates (chemical analysis, granularity, porosity, compactness, etc...); 
- An evaluation of the effect of the nature of the sand on the properties of SCCs in the fresh state such as: dynamic segregation, spreading diameter, etc;

- Mechanical properties (mechanical tests on concrete made from local materials).

This research work is a contribution to the improvement of the properties of selfcompacting concretes based on local materials. Further, to see the possibility of recovery of slag as a mineral industrial wastes for the manufacture of a SCC based on these type of fillers additives.

\section{Physical Characteristics of the Materials Used}

The choice of materials, first was on their availability in the region of M'SILA (semi-arid region). Therefore, we describe in the following paragraphs the different analyses of the materials used according to NF [7].

\subsection{Aggregates}

\subsubsection{Physical characteristics}

The gravel used is crushed and comes from the BBA region. Two fractions of aggregates are used for the composition of SCCs: (3/8) and (8/15). And two types of sand were used: a quarry sand (crushed) of calcareous origin from COSIDER and a sand of Oued Maiter of siliceous origin from the region of Bousaada (OUED MAITER). The physical characteristics of the aggregates used are summarized in Table 1.

\subsubsection{Chemical compositions}

The chemical composition is established at the CCA's cement plant. It is given by the table below:

\subsubsection{Granulometric analysis}

According to the granulometric analysis of sand dune, more than $50 \%$ of the curve is outside the sand specification limits for concretes as shown in Figure 1. We infer that it is a fine sand of a low quality. On the other hand, the crushed sand is located in the sand specification zone. So, we can consider it as a preferential sand. 
TABLE 1: Chemical composition of the materials used.

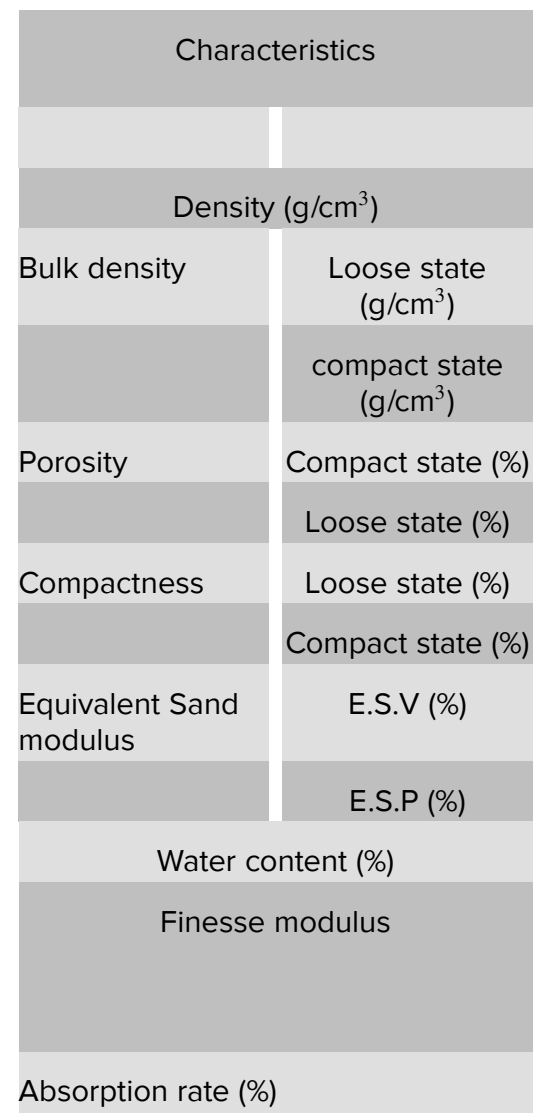

\begin{tabular}{|c|c|}
\hline $\begin{array}{c}\text { Dune } \\
\text { sand }\end{array}$ & N.B \\
\hline 2.54 & $/$ \\
\hline 1.55 & $/$ \\
\hline 1.79 & $/$ \\
\hline 38.97 & $/$ \\
\hline 29.89 & $/$ \\
\hline 61.03 & $/$ \\
\hline 70.11 & $/$ \\
\hline 78.21 & $\begin{array}{c}\text { Clean } \\
\text { sand }\end{array}$ \\
\hline 72.82 & \\
\hline 1.26 & $/$ \\
\hline 1.85 & $\begin{array}{c}\text { A sand } \\
\text { with low } \\
\text { fines } \\
\text { content }\end{array}$ \\
\hline 2.41 & $/$ \\
\hline
\end{tabular}
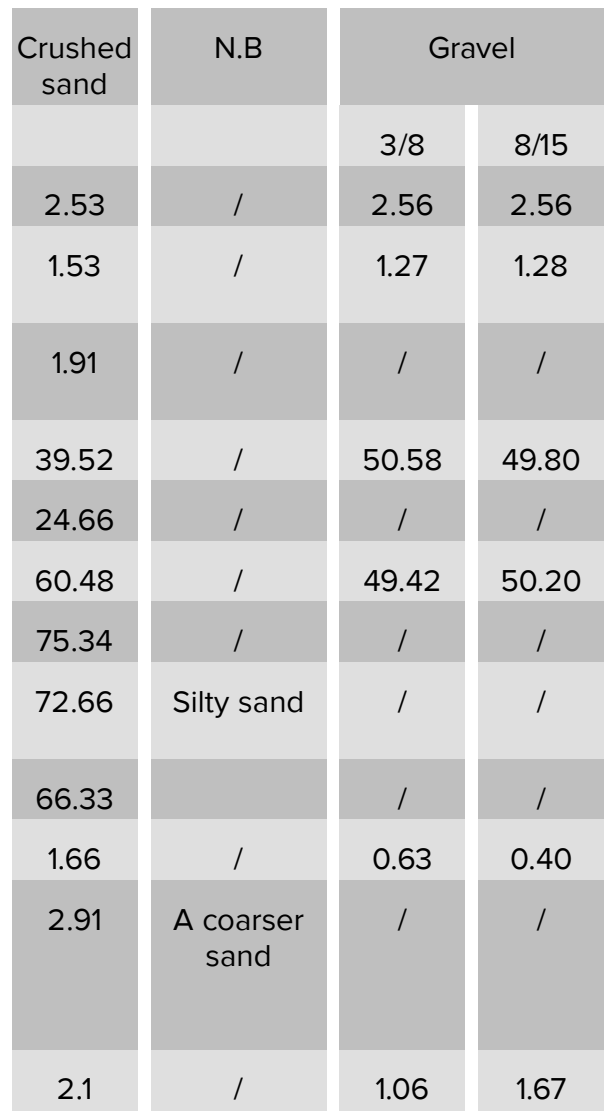

TABLE 2: Chemical compositions of the materials used.

\begin{tabular}{l|c|c|c|c|c|c|c|c|}
\hline Elements / Materials & $\mathrm{SiO}_{2}$ & $\mathrm{Al}_{2} \mathrm{O}_{3}$ & $\mathrm{Ca} O$ & $\mathrm{Fe}_{2} \mathrm{O}_{3}$ & $\mathrm{SO}_{3}$ & $\mathrm{MgO}$ & $\mathrm{K}_{2} \mathrm{O}$ & $\mathrm{Na}_{2} \mathrm{O}$ \\
\hline Dune sand & 80.14 & 1.84 & 10.50 & 0.01 & $/$ & 0.44 & $/$ & $/$ \\
\hline Crushed stone sand & 40.65 & 8.87 & 40.56 & 3.25 & 0.79 & 3.65 & 0.65 & 0.01 \\
\hline
\end{tabular}

Dune sand is a very pure sand with a high silica content.

\subsection{Cement}

The cement used in is a blended Portland cement 42.5 grade. Its density is 3.1 with fineness around $4000 \mathrm{~cm}^{2} / \mathrm{g}$ and Its chemical composition is shown in Table 3.

TABLE 3: Chemical composition of the cement used in\%.

\begin{tabular}{l|c|c|c|c|c|c|c|}
\hline Elements & $\mathrm{SiO}_{2}$ & $\mathrm{AL}_{2} \mathrm{O}_{3}$ & $\mathrm{Ca} O$ & $\mathrm{Fe}_{2} \mathrm{O}_{3}$ & $\mathrm{SO}_{3}$ & $\mathrm{MgO}$ & $\mathrm{Na}_{2} \mathrm{O}$ \\
\hline content(\%) & 20.7 & 4.75 & 62.92 & 3.75 & 1.98 & 1.92 & 0.09 \\
\hline
\end{tabular}




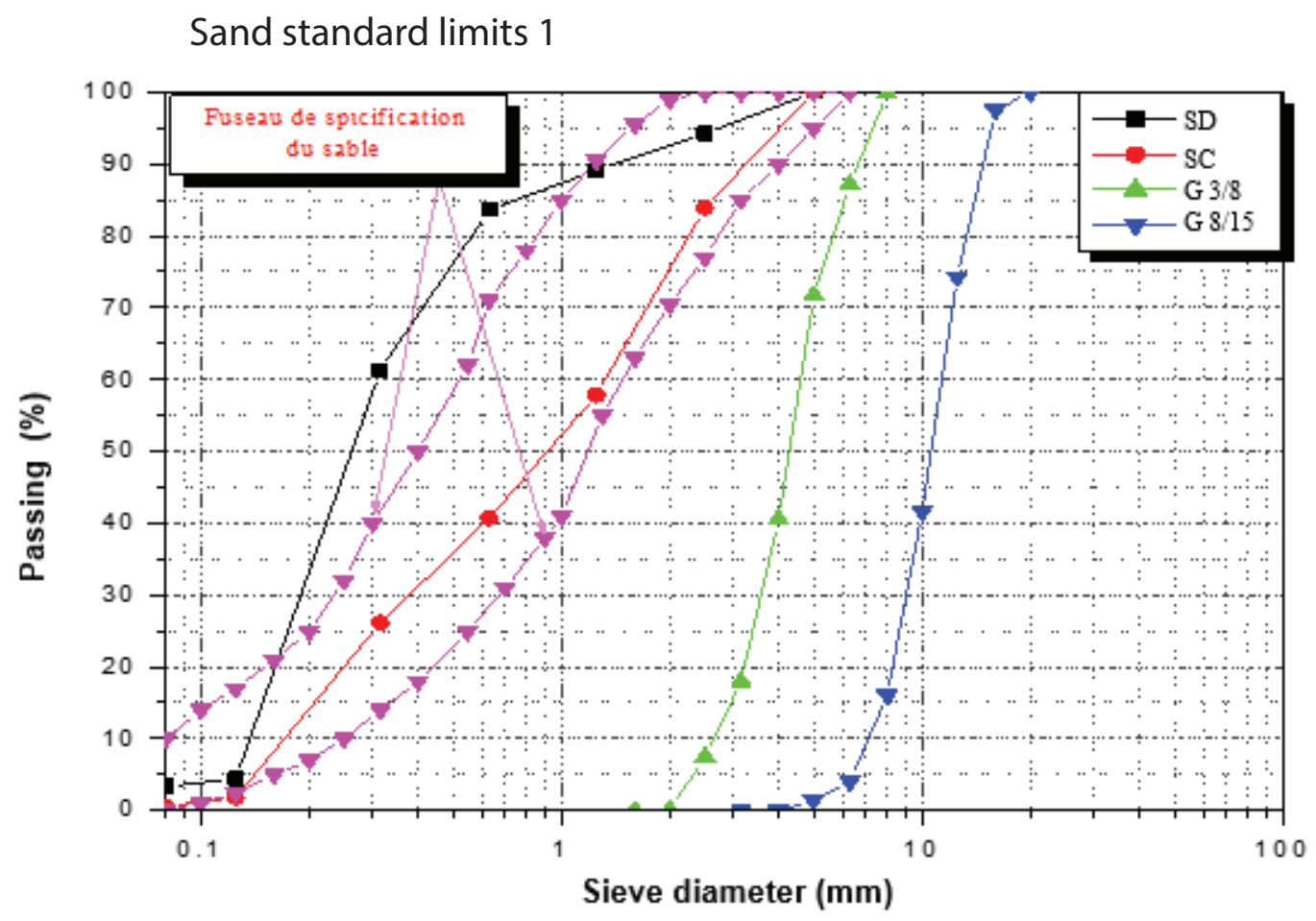

Figure 1: Sieve analysis curve of aggregates

\subsection{Admixture}

A superplasticizer of the MEDAFLOW 30 type based on polycarboxylates of Ether; has been used to ensure a satisfactory fluidity for the different formulations. It belongs to the family of highly water reducer -based superplasticizers. Its density is $1.07( \pm 0.1)$, its $\mathrm{Ph}$ is $6(+0.5)$, the solids contents presents $34 \%$. The recommended dosage ranges from 0.5 to $2.0 \%$ of the cement weight ( $\mathrm{l}, \mathrm{e} ; 0.46$ to 1.85 litres per $100 \mathrm{~kg}$ of cement).

\subsection{Granulated slag}

The granulated slag of the Annaba blast furnace plant is used as filler, it is under light coloured sand, with a bulk density of $1.21 \mathrm{~g} / \mathrm{cm}^{3}$, a specific density of $2.94 \mathrm{~g} / \mathrm{cm}^{3}$ and a fineness of $2600 \mathrm{~cm}^{2} / \mathrm{g}$. Its chemical composition is shown in Table 4.

TABLE 4: Chemical composition of the slag used in\%.

\begin{tabular}{l|c|c|c|c|c|c|c|c|c|}
\hline Elements & $\mathrm{SiO}_{2}$ & $\mathrm{Al}_{2} \mathrm{O}_{3}$ & $\mathrm{Fe}_{2} \mathrm{O}_{3}$ & $\mathrm{CaO}$ & $\mathrm{MgO}$ & $\mathrm{SO}_{3}$ & $\mathrm{Na}_{2} \mathrm{O}$ & $\mathrm{K}_{2} \mathrm{O}$ & $\mathrm{Cl}-$ \\
\hline Content(\%) & 40.8 & 5.2 & 0.53 & 43.01 & 6.4 & 0.8 & 0.01 & 3.02 & 0.007 \\
\hline
\end{tabular}




\subsection{Viscosity agent}

MEDACOL BSE is an additive for the manufacture of concretes and mortars cast in water. It makes the concrete more plastic or even viscous, which facilitates concreting under water, without leaching or segregation. With the addition of a super plasticizer, the same concrete can be pumped with a very low W/C ratio compared to a control concrete pumped under the same conditions. Its density is 0.5 [8].

\subsection{Limestone powder}

This is fine limestone from the region of Biskra, the specific surface is $2600 \mathrm{~cm}^{2} / \mathrm{g}$, the absolute density is $2.66 \mathrm{~g} / \mathrm{cm}^{3}$. The chemical composition of limestone is shown in Table 5.

TABLE 5: Chemical Composition of cement and Limestone used.

\begin{tabular}{|l|c|c|c|c|c|c|c|c|c|}
\hline Elements (\%) & $\mathrm{SiO}_{2}$ & $\mathrm{Al}_{2} \mathrm{O}_{3}$ & $\mathrm{Fe}_{2} \mathrm{O}_{3}$ & $\mathrm{CaO}$ & $\mathrm{MgO}$ & $\mathrm{SO}_{3}$ & $\mathrm{Na}_{2} \mathrm{O}$ & $\mathrm{K}_{2} \mathrm{O}$ & $\mathrm{PAF}$ \\
\hline Limestone & 10.81 & 0.31 & 0.76 & 47.51 & 0.21 & - & - & - & 40.69 \\
\hline
\end{tabular}

\section{Composition of Self-compacting Concrete}

The formulation of the SCCs was made according to FACG (French Association of Civil Engineering) [9]. The concrete parameters are set as shown in Table 6.

TABLE 6: The fixed parameters of self-placing concrete.

\begin{tabular}{l|c|c|c|c|}
\hline Characteristics & W/C ratio & F/C ratio & $\begin{array}{c}\text { the superplas- } \\
\text { ticizer } \\
\text { dosage }\end{array}$ & viscosity agent dosing \\
\hline values & 0.5 & 0.25 & $1.5 \%$ & \multicolumn{1}{c|}{$0.1 \%$} \\
\hline Characteristics & G/S ratio & sand dosage & $\begin{array}{c}\text { the dosage in } \\
\text { aggregates }\end{array}$ & $\begin{array}{c}\text { Volume of } \\
\text { paste (fixe) }\end{array}$ \\
\hline values & 1 & $850 \mathrm{~kg} / \mathrm{m}^{3}$ & $850 \mathrm{~kg} / \mathrm{m}^{3}$ & 370 I
\end{tabular}

The composition of the concrete used in this study is summarized in the table below:

\section{Formulation of Normal Concrete}

The composition of the concrete used is determined by the Dreux-Gorisse method [10]. 
TABLE 7: The composition of prepared mixtures of concrete in $\mathrm{kg} / \mathrm{m}^{3}$.

\begin{tabular}{|c|c|c|c|c|c|c|c|c|c|c|}
\hline & Cement & water & slag & $\begin{array}{l}\text { Lime- } \\
\text { stone }\end{array}$ & $\begin{array}{c}\text { Gravel } \\
3 / 8\end{array}$ & $\begin{array}{c}\text { Gravel } \\
8 / 15\end{array}$ & $\begin{array}{l}\text { Dune } \\
\text { sand }\end{array}$ & $\begin{array}{c}\text { Crushed } \\
\text { sand }\end{array}$ & $\begin{array}{c}\text { Medaflow } \\
30\end{array}$ & $\begin{array}{c}\text { Medacol e } \\
\text { BSE }\end{array}$ \\
\hline $\mathrm{BAP}^{*}$ & 400 & 200 & 100 & I & 425 & 425 & 850 & 0 & 6 & 0.2 \\
\hline BAP $2 \mu$ & 400 & 200 & 1 & 100 & 425 & 425 & 850 & 0 & 6 & 0.2 \\
\hline BAP3\$ & 400 & 200 & 100 & I & 425 & 425 & 425 & 425 & 6 & 0.2 \\
\hline BAP4£ & 400 & 200 & I & 100 & 425 & 425 & 425 & 425 & 6 & 0.2 \\
\hline
\end{tabular}

* BAP1, refers to SCC with slag and dune sand100 \% dune sand

$\mu$ BAP2, refers to SCC with limestone and $100 \%$ dune sand

$\$$ BAP3, refers to SCC with salg addition and mixed sand.

$£$ BAP4, refers to SCC with limestone addition and mixes sand.

TABLE 8: The composition of a $\mathrm{m}^{3}$ of ordinary concrete:

\begin{tabular}{|c|c|c|c|c|c|c|c|}
\hline & cement & water & sand & $\begin{array}{c}\text { Com- } \\
\text { Gproasvietilo- } \\
3 \mathrm{n} / 8 \mathrm{~kg} \\
/ \mathrm{m}^{3}\end{array}$ & Gravel 8/16 & Superplasticizer & $\mathrm{W} / \mathrm{C}$ \\
\hline BV1 & 400 & 220 & 592.40 & 2174.92 & 928.40 & & 0.5 \\
\hline BV2 & 400 & 220 & 592.40 & 2174.92 & 928.40 & 4 & 0.5 \\
\hline
\end{tabular}

\section{Results and Discussion}

\section{1. influence of the nature of sand on the behavior of concrete at fresh state}

\subsubsection{Workability}

The results of the rheological properties of different SCCs mixtures (filling capacity, spreading diameter, segregation) are illustrated in the following figures 2, 3 and 4 .

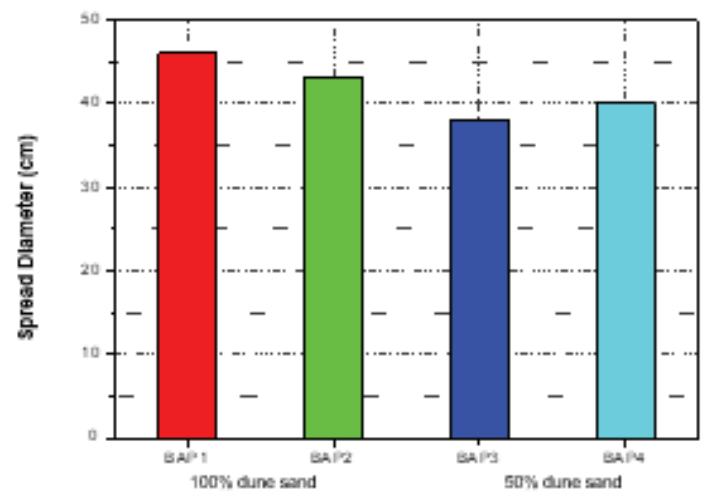

Figure 2: Influence of the nature of sand on the Fluidity (fow table test) of studied SCCs

Figures (2, 3 and 4) clearly show the difference between the results obtained (the flow table diameter, the ease of placing and the segregation index), which is explained 


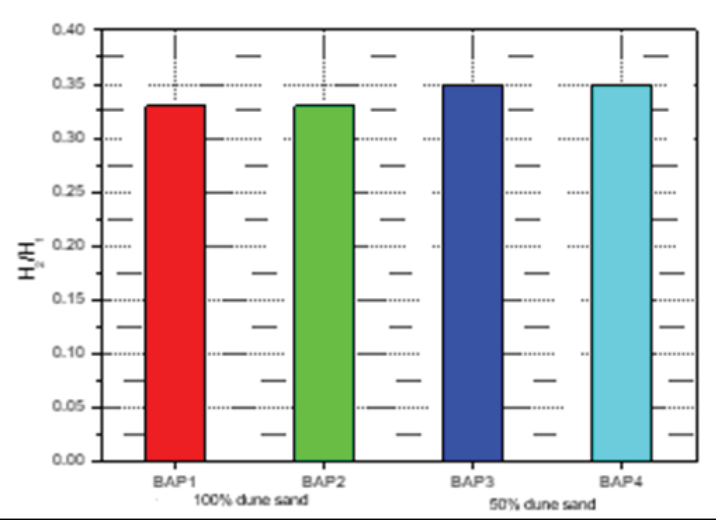

Figure 3: Influence of the nature of sand on the passing ability ( $L$ box test) of studied SCCS

by the internal structure of the concrete, that is very complex. and granulometry of the sands.

It can be seen that cracked sand has a negative influence on the spreading diameter and the segregation index. On the other hand, the degree of filling $(\mathrm{H} 2 / \mathrm{H} 1)$ is a little higher compared to concrete prepared with sand dune. This increase does not mean that the quantity of chemical water has been exceeded, but the need for water in the fresh material, to reach a suitable workability, is strongly influenced by the surface texture, the porosity and the shape of the aggregates. In the case of crushed aggregates, the loss of workability may be due to a greater or lesser absorption of water depending on the porosity of the aggregate and its degree of saturation.

It is reasonable to think that, for concretes prepared from crushed sand, the cement produces pastas that are less manageable, unlike those obtained for concrete based on sand dune which is characterized by poor adhesion - aggregates - binder.

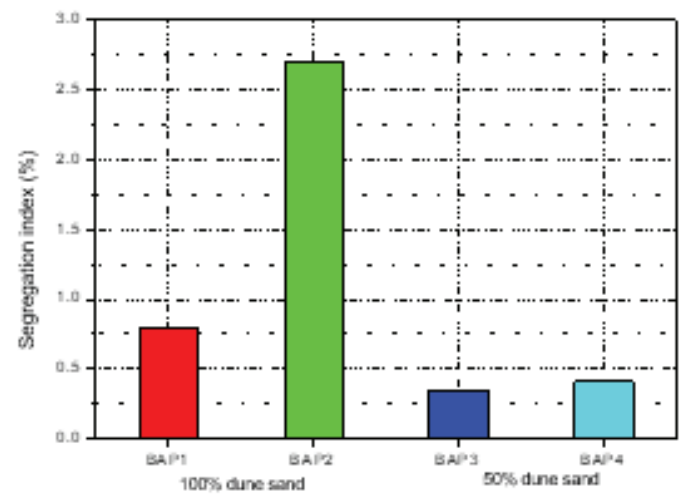

Figure 4: Influence of the nature of sand on the segregation index of studied SCC

As a result, the dough-aggregate interface plays a vital role in the structure of the concrete. When modelled by a perfect bond, idealization is too advanced and therefore penalizing. 


\subsubsection{The hardened state}

The compressive strength is estimated by crushing the $10 \times 10 \times 10 \mathrm{~cm}$ cubic specimens at 14 days, 28 days and 45 days of curing in a humid environment at $\mathrm{RH} 90 \%$ and and ambient temperature of $22{ }^{\circ} \mathrm{C}$. In addition, the tensile strength is evaluated by splitting tests of $16 \times 32 \mathrm{~cm}$ cylindrical specimens (Brazilian test) at 28 days hardening. The results obtained are illustrated in the following figures 5 and 5 ;

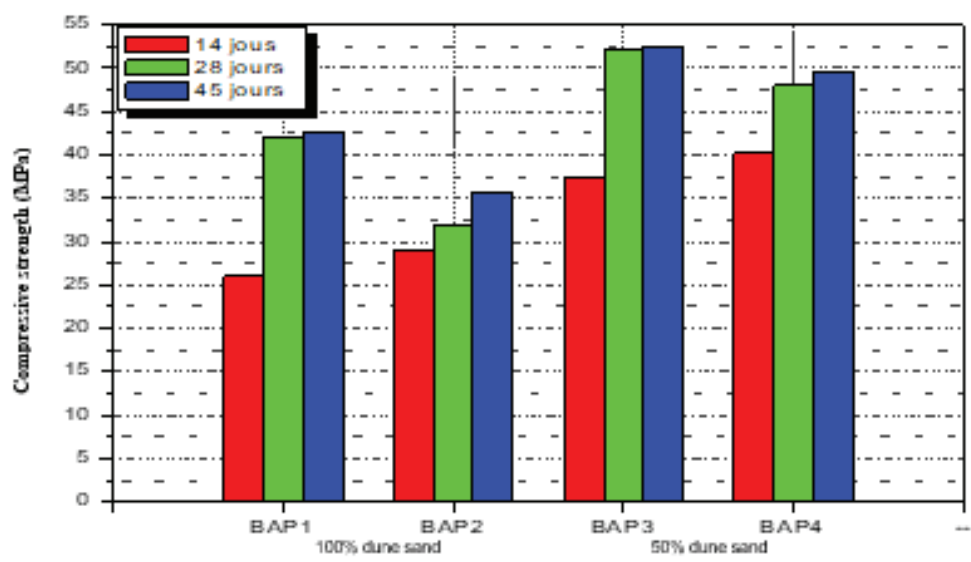

Figure 5: Influence of the nature of sand on the compressive strength of studied SCCs

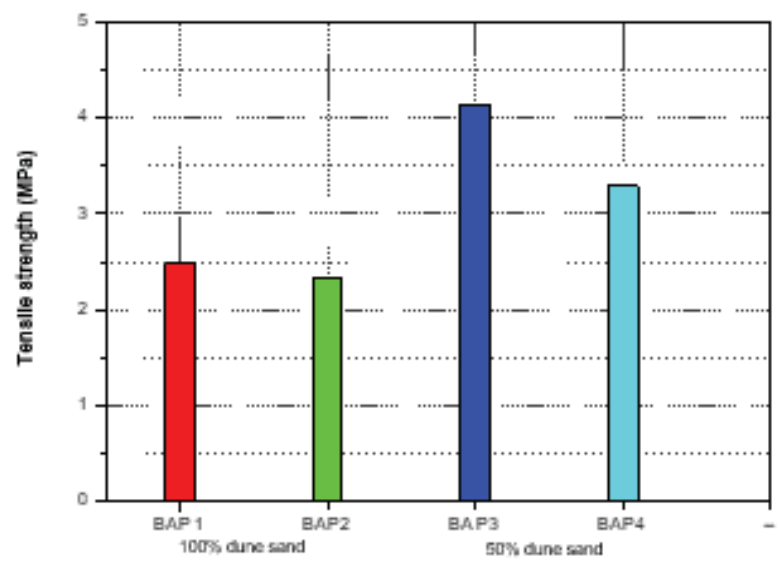

Figure 6: Influence of the nature of sand on the tensile strength of studied SCCs

The effect of slag on compressive strength is beneficial in comparison with limestone. The slag has the same effect on SCCs as that on ordinary concretes, which can be explained by the reaction of slag constituents with portlandite to form dense C.S.H, and consequently the increase in compactness. In addition, we have shown the positive influence of the presence of crushed aggregates on the mechanical strength, the modulus of elasticity and the absorption coefficient. Consequently, it is therefore necessary to think that the rings surrounding the aggregates constitute drainage zones 


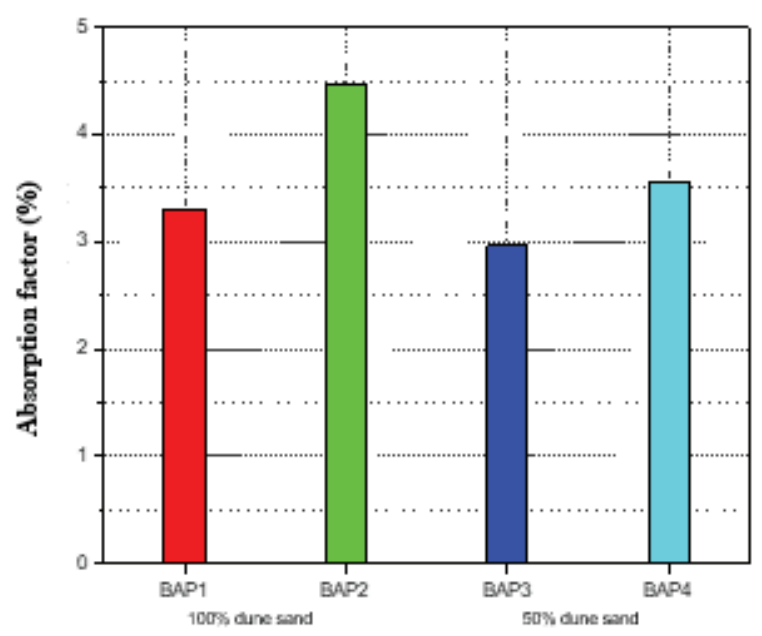

Figure 7: Influence of the nature of sand on the absorption factor of studied SCCY

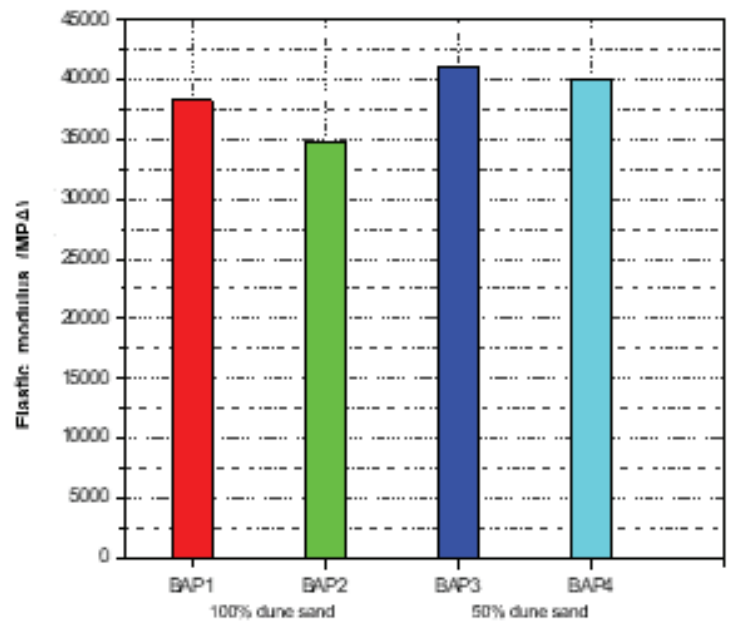

Figure 8: Influence of the nature of sand on the elastic modulus of studied SCCY

which thus restore the continuity of the porous network, initially continuous in a young paste, but which was then segmented during aging. This translates to the resistance gain that exceeds $20 \%$ at 45 days. Finally, we recommend using crushed aggregates with slag fillers because they are very profitable for making resistant concrete.

\subsection{Comparison between SCC and ordinary concrete}

Figure 9 shows the mechanical strength of SCCs in compression compared with ordinary concrete. This can be explained by a high W/C ratio equal to 0.5 for ordinary concrete compared to a $\mathrm{W} /$ Binder $=0.40$ for a SCCs. In addition, depending on the internal structure of the concrete, the free water containing hydrates varies between the hydrate points depending on the type and age of the concrete, which creates pores between 

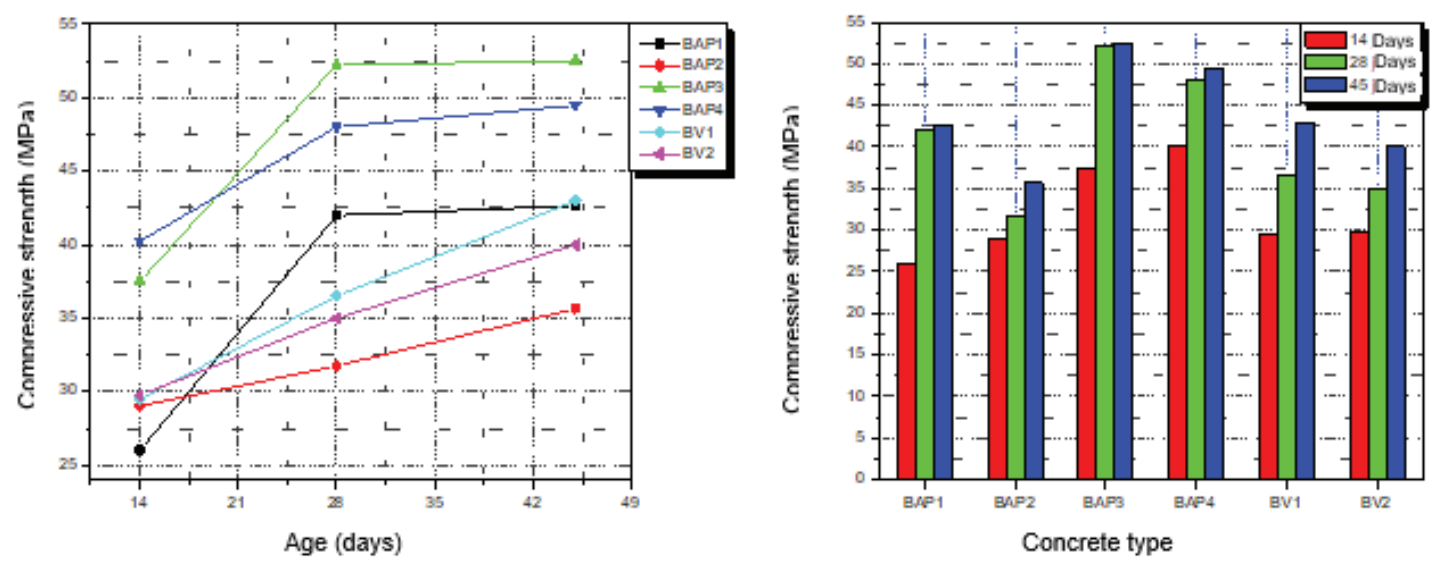

Figure 9: Influence of the nature of sand on the compressive strength of studied SCCY and reference mixture.

the hydrate particles progressively up to the $\mathrm{W} / \mathrm{C}$ value. $=0.5$ on the one hand and the extension of the capillary voids on the other hand (it is about the capillary pores which are the vestiges of the inter-granular spaces left by the hydration of the cement paste). Because the hydrates formed at the bottom of the value ( $\mathrm{W} / \mathrm{C}=0.5$ ), are rapidly densified (the case of the different SCCS) because of the compatibility between the mixing water and the chemical water (faster curing). that is, the duration of the hydration is short). In addition, for the highest I / C ratios, the capillary network remains interconnected, which translates into a decrease in resistance [11].

\section{Conclusion}

The work presented concerns the development of a new type of cementitious composite (SCCS), based on crushed sand; evaluating the influence of this sand on the Physico- mechanical properties, at a weight content equal to $50 \%$. So, from the results obtained, we can conclude that the use of crushed sand improves the quality of the concrete. However, to obtain a good quality concrete based on crushed sand, it is strongly recommended to use slag fillers that improve the rheological behaviour at the fresh state, this could contribute to achieve a self-placing concrete within acceptable performances at the hard state of SCCs. 


\section{References}

[1] Fares H. "Propriétés mécaniques et physico-chimiques de bétons autoplaçants exposés à une tempurature élevée ". Thèse de doctorat, université de GergyPontoise, 07/12/2000, 07.

[2] Bensebti S. "Formulation et Propriétés des Bétons Autoplaçants à Base de Matériaux Locaux ". Thèse de doctorat, Université Mentouri-Constantine, 02/07/2008, P-1, 2008.

[3] Hamouine A, Rikioui T. Fabrication du béton autoplaçant à base des matériaux locaux de la région de Saoura. Séminaire sur les technologies du béton, 2004.

[4] Audenaert K, V. Boel, V, \& Schutter G.D. Carbonation of Self Compacting Concrete. 6th International Symposium on High Strength/High Performance Concrete, Leipzig, June, 2002, 853-862, 2003.

[5] Okamura H, Ouchi M. Self-Compacting Concrete. Journal of Advanced Concrete Technology, 1 (1) (2003), 5-15.

[6] Collection technique CIM Béton. "Les bétons: formulation, fabrication et mise en œuvre", G11-Tome2, Octobre 2006,110-119, 2006.

[7] Dupain R, Lanchon R, Saint Arroman J C. "Granulats, Sols, Ciments et Granulats". Editions CASTEILLLA, ISB 2.7135-1471-1, Paris, 03-33, 1995.

[8] Recueil technique GRANITEX, (2008)., p: 45 et 58-59.

[9] AFGC Bétons auto-plaçants, (2000). Recommandations previsoires. Association Française du Génie Civil.

[10] Georges Dreux, Jean Festa. "Nouveau guide du béton". Editions Eyrolles, Paris 1995, 156- 202. ISBN ISBN 2-212-10230-5

[11] Baron J. Introduction à la durabilité des bétons, La durabilité des bétons. Presses de l'école nationale des ponts et chaussées, ISBN 2-85978-184-6, Paris 1992, 23 -38. 